\author{
Anna Kozłowska \\ https://orcid.org/0000-0001-6843-5981 \\ Uniwersytet Łódzki \\ Instytut Geografii Miast i Turyzmu \\ Zakład Geografii Hotelarstwa \\ anna.kozlowska@geo.uni.lodz.pl
}

\title{
PRODUKT GASTRONOMICZNY W HOTELACH W ŁODZI
}

\begin{abstract}
Abstrakt: Restauracje oraz inne obiekty świadczące usługi gastronomiczne stanowią istotną część hoteli, mogą być ich wizytówką lub decydować o ich niepowtarzalności. Zgodnie z Rozporzadzeniem Ministra Gospodarki i Pracy z dnia 19 sierpnia 2004 r. w sprawie obiektów hotelarskich $i$ innych obiektów, w których sq świadczone ustugi hotelarskie gestorzy mają obowiązek świadczenia usług gastronomicznych w hotelu. Jednak mimo dynamicznego rozwoju gastronomii w XXI w. prowadzenie obiektów znajdujących się w hotelach jest często dla gestorów obowiązkiem, a nie źródłem dodatkowego dochodu.

W niniejszym artykule został zaprezentowany produkt gastronomiczny w łódzkich hotelach, rozumiany jako wszystkie usługi w hotelu związane z gastronomią. Analiza została przeprowadzona pod kątem marki obiektów, oferty związanej z lokalną kuchnią oraz dostępności gastronomii hotelowej dla potencjalnych gości. Ponadto wyróżniono czynniki, które mogą ułatwić dostęp do gastronomii hotelowej, przełamując jej stereotyp jako uznawanej za dostępną tylko dla osób korzystających z noclegu, oraz przedstawiono zalety dobrego wykorzystania możliwości produktu gastronomicznego hotelu.
\end{abstract}

Słowa kluczowe: produkt gastronomiczny hotelu, restauracja hotelowa, gastronomia hotelowa, Łódź.

\section{WSTĘP}

W Łodzi mają miejsce wydarzenia gastronomiczne o ustalonej renomie, odbywające się regularnie od kilku lat, znane w Polsce i w Europie. Należą do nich m.in. Festiwal Dobrego Smaku czy Międzynarodowe Targi Żywności Ekologicznej i Naturalnej Natura Food (Kozłowska, 2015). Jednocześnie w Łodzi nie ma wytyczonych szlaków kulinarnych, a regionalna kuchnia czy produkty turystyczne oparte na dziedzictwie kulinarnym miasta nie istnieją lub nie są dostatecznie rozwinięte. W ostatnich latach można jednak zaobserwować pozytywne zmiany. Stopniowo powstają restauracje oraz przestrzenie miejskie, które wyróżniają się na mapie kulinarnej Polski (Stasiak, 2015). Na uwagę zasługują lokale umiejscowione w zabytkowych wnętrzach, m.in. w budynkach pofabrycznych, bardzo charakterystycznych dla zabudowy Łodzi.

Lokale gastronomiczne w hotelach najczęściej kojarzone są z wysokim standardem oraz uniwersalnością, a menu przygotowuje się $w$ nich $w$ taki sposób, by zapewnić możliwość wyżywienia różnych klientów, bez względu na miejsce ich pochodzenia czy uwarunkowania kulturowe. Wszystkie związane z gastronomią usługi oferowane $\mathrm{w}$ hotelach tworzą produkt gastronomiczny hotelu, będący podstawowym komponentem produktu hotelowego. Ustawa $z$ dnia 29 sierpnia
1997 r. o ustugach hotelarskich oraz ustugach pilotów wycieczek i przewodników turystycznych zobowiązuje właścicieli hoteli do świadczenia przynajmniej podstawowych usług gastronomicznych. Produkt gastronomiczny wyróżnia się składnikami materialnymi (wyprodukowanymi dobrami) oraz niematerialnymi, w tym szeroko pojętą gościnnością, np.: sposobem i czasem obsługi, znajomością języków obcych przez pracowników czy panującą w lokalu atmosferą (Milewska, Prączko, Stasiak, 2017). Na produkt gastronomiczny składa się to, co zaspokaja głód konsumentów (osób korzystających z danych usług), oraz wszystko to, co wpływa na ich zadowolenie poprzez sprostanie także innym potrzebom, np.: doświadczenia obcej kultury lub estetyki wnętrz, zaspokojenia potrzeby społecznej - poprzez wizytę w popularnym obiekcie (Stasiak, 2007).

Wymienione elementy produktu gastronomicznego można podzielić na trzy poziomy. Centralną, podstawową część stanowi rdzeń produktu (zaspokojenie głodu, osiągnięcie stanu sytości), zwykle wzbogacony o składowe, które podnoszą jego wartość i atrakcyjność na rynku. Kolejny wyróżniony poziom to produkt rzeczywisty, czyli elementy kreujące produkt, wpływające na sposób postrzegania go przez klientów (np.: cena produktu, nazwa dania, sposób podania). 
Trzecim z uwzględnionych aspektów produktu gastronomicznego są wszystkie dodatkowe cechy i korzyści, które wspólnie składają się na produkt rozszerzony (np. dostępność usługi, sposób rezerwacji i płatności) (Milewska, Włodarczyk, 2015; Sala, 2011). Duża konkurencja na rynku gastronomicznym powoduje, że lokale wzbogacają swoją ofertę o coraz to atrakcyjniejsze elementy produktu rozszerzonego, np.: obecność w mediach społecznościowych i portalach internetowych umożliwiających dowóz jedzenia oraz nowe sposoby rezerwacji (rezerwacje internetowe, telefoniczne, poprzez aplikacje). Elementy produktu rozszerzonego stają się wizytówką zakładów gastronomicznych, ich wyróżnikiem na rynku, i stanowią element decydujący o wyborze danej restauracji przez klientów. Produkt gastronomiczny hotelu może przynosić istotne dodatkowe dochody oraz stwarzać szansę promocji całego obiektu. Coraz częściej właściciele rozszerzają ofertę usług o organizację imprez okolicznościowych, wykorzystując zaplecze gastronomiczne hotelu (organizacja wesel, konsolacji czy przerw kawowych podczas konferencji).

Restauracje hotelowe różnią się od obiektów "zlokalizowanych przy ulicach”, ponieważ w większości przypadków muszą dostosowywać się do standardów hotelu oraz wymagań wynikających z kategorii obiektów (Gordin, Trabskaya, Zelenskaya, 2016). Charakteryzując produkt gastronomiczny hotelu, należy uwzględnić także markę hotelu oraz wpływ działalności obiektu na restaurację.

Autorka dokonała przeglądu literatury i stwierdziła, że nie ma opracowań dotyczących produktu łódzkiej gastronomii hotelowej. Celem niniejszego artykułu jest więc charakterystyka produktów gastronomicznych w łódzkich hotelach pod względem lokalizacji obiektów, ich dostępności dla gości oraz reprezentowanej marki. Autorka bada wpływ tych czynników na atrakcyjność produktu gastronomii hotelowej w Łodzi.

\section{PRZEGLĄD LITERATURY}

Gastronomia zyskuje popularność, stając się odrębnym produktem turystycznym, a nie tylko uzupełnieniem oferty czy dodatkową usługą. Świadomość konsumentów rośnie, podobnie jak ich wymagania co do serwowanych potraw, sposobu ich podania czy wyglądu wnętrz. W literaturze istnieją opracowania dotyczące turystyki kulinarnej - m.in. kuchni regionalnych, gastronomicznych produktów turystycznych czy form organizacji turystyki kulinarnej (Jędrysiak, Orłowski, Woźniczko, 2015; Kwiatkowska, Levytska, 2009).

W Polsce problematyka gastronomii jest omawiana głównie teoretycznie. Badacze piszą na ten temat, opierając się na sytuacji na rynkach zagranicznych lub na danych Głównego Urzędu Statystycznego. W 2015 r. w Łodzi odbyła się konferencja „Kultura i turystyka - wokół wspólnego stołu”, podczas której poruszono również zagadnienia związane $\mathrm{z}$ gastronomią $\mathrm{w}$ hotelarstwie. W monografii, która powstała po konferencji, podkreślony został fakt, że "stosunkowo niewiele artykułów bazuje na podstawowych badaniach empirycznych" (Krakowiak, Stasiak, 2015, s. 5-6). W literaturze zagranicznej znajdziemy prace napisane na podstawie badań empirycznych dotyczących gastronomii hotelowej lub konkretnych produktów gastronomicznych, znaczenia kuchni lokalnej w ofercie gastronomicznej hoteli i jej wpływu na tworzenie marki regionu (Björk, Kauppinen-Räisänen, 2017; Gordin, Trabskaya, Zelenska, 2016; Kapera, 2015). Dostępne są również rzetelne dane o potencjale turystyki kulinarnej w Łodzi (Stasiak, 2015) oraz lokalizacji hoteli w tym mieście (Włodarczyk, 2015), brakuje natomiast publikacji dotyczących gastronomii hotelowej w Łodzi.

\section{METODA BADAWCZA}

Autorka przeprowadziła badania w 33 skategoryzowanych hotelach w Łodzi, w okresie styczeń-maj 2018 r. Pierwszym źródłem informacji o obiektach była strona internetowa www.turystyka.gov.pl (Centralna Ewidencja i Wykazy w Turystyce, Ministerstwo Turystyki). Dane uzyskane ze strony zostały porównane ze stanem faktycznym i na tej podstawie stwierdzono, że w 2018 r. dwa obiekty wymienione $\mathrm{w}$ portalu nie pełniły już funkcji hotelu. Autorski kwestionariusz ankiety składał się z czterech części, tj. z pytań dotyczących stanu bazy gastronomicznej w obiekcie, oferty gastronomicznej związanej z salami wielofunkcyjnymi, strategii marketingowej obiektu w kontekście gastronomii oraz formalnych i finansowych zależności obiektu gastronomicznego od hotelu. Badania zostały przeprowadzone na trzy sposoby: osobiście, za pomocą formularza internetowego ankiety oraz poprzez wywiady telefoniczne. Pięciu gestorów odmówiło udziału w badaniu. Kwestionariusze ankiet zostały uzupełnione o informacje $\mathrm{z}$ oficjalnych stron internetowych hoteli.

Analizując zebrane materiały, autorka posłużyła się tekstem Ustawy z dnia 29 sierpnia 1997 r. o ustugach hotelarskich oraz ustugach pilotów wycieczek i przewodników turystycznych oraz Rozporzadzenia Ministra Gospodarki i Pracy z dnia 19 sierpnia 2004 r. w sprawie obiektów hotelarskich $i$ innych obiektów, w których sa świadczone ustugi hotelarskie, literaturą dotyczącą gastronomii i hotelarstwa, a także danymi z portalu TripAdvisor. Mapę do artykułu przygotowano w programie ArcMapa 10.4.1, podkłady zostały pozyskane ze strony Łódzkiego Internetowego Systemu Informacji o Terenie, z serwisu WMS (InterSIT). 


\section{CHARAKTERYSTYKA GASTRONOMII W ŁÓDZKICH HOTELACH}

Hotel definiowany jest jako obiekt noclegowy posiadający co najmniej 10 pokoi, głównie jedno- i dwuosobowych, świadczący szereg usług związanych z pobytem gościa (Ustawa, 1997). Jedną z dostępnych w hotelach usług jest gastronomiczna. W Rozporzadzeniu Ministra Gospodarki i Pracy z dnia 19 sierpnia 2004 r. w sprawie obiektów hotelarskich i innych obiektów, w których sq świadczone ustugi hotelarskie zostały określone wymagania dla poszczególnych kategorii obiektów hotelarskich (tab. 1) odnośnie do ich wyposażenia oraz zakresu świadczonych usług. Z dokumentu wynika, że gestor nie ma prawa posługiwać się nazwą „hotel” bez świadczenia usług związanych $\mathrm{z}$ gastronomią. Ponadto wspomniane rozporządzenie $\mathrm{m}$.in. nakłada na hotele pięcio-, cztero- i trzygwiazdkowe obowiązek posiadania restauracji oraz wydawania śniadań i sprzedaży ciepłych napojów (tab. 1). W Ustawie z dnia 29 sierpnia 1997 r. o ustugach hotelarskich oraz ustugach pilotów wycieczek i przewodników turystycznych nie ma definicji lokalu (tj. restauracji), o którym mowa w Rozporządzeniu Ministra Gospodarki i Pracy z dnia 19 sierpnia 2004 r. w sprawie obiektów hotelarskich i innych obiektów, w których sa świadczone ustugi hotelarskie.

Milewska, Prączko i Stasiak (2017) definiują zakład gastronomiczny typu „restauracja” jako dostępny dla ogółu konsumentów lokal z pełną obsługą kelnerską, oferujący szeroki asortyment potraw i napojów według menu. Hotele jedno- i dwugwiazdkowe nie są zobowiązane do posiadania restauracji czy innych lokali gastronomicznych, jednak w swojej ofercie muszą mieć śniadania. Obowiązek ten gestorzy realizują poprzez przygotowywanie śniadań na miejscu albo współpracę z firmą zewnętrzną, zajmującą się cateringiem śniadaniowym. Współpraca $z$ takimi firmami odbywa się również przy organizacji imprez okolicznościowych, takich jak wesela czy chrzciny, lub przerw kawowych podczas konferencji. Tak jest w przypadku hotelu Eskulap, który nie posiada zaplecza gastronomicznego, ale zawarł umowę o stałej współpracy z firmą dostarczającą śniadania oraz organizującą w hotelu imprezy okolicznościowe.

W 33 skategoryzowanych hotelach w Łodzi jest w sumie ok. 5200 miejsc noclegowych (stan na wrzesień 2018 r.). W Łodzi nie ma obiektów zaliczanych do najwyższej kategorii - pięciogwiazdkowych. Najwięcej jest hoteli trzygwiazdkowych (16) oraz dwugwiazdkowych (10). Istnieją także dwa obiekty jednogwiazdkowe i pięć czterogwiazdkowych.

W czasie badania, którym objęto 33 hotele, w 6 z nich (18\%) nie było czynnego zakładu gastronomicznego (rys. 1), w tym w jednym trzygwiazdkowym. W trakcie badań w restauracji był przeprowadzany remont. W pozostałych 27 łódzkich hotelach występowały tylko dwa typy obiektów gastronomicznych - restauracja lub bar. W żadnym z inwentaryzowanych obiektów nie było m.in.: lokalu nocnego, stołówki, punktu gastronomicznego czy kawiarni, wymienianych w literaturze jako popularne lokale gastronomiczne występujące w hotelach (Sala, 2011). Hotel Alicja jako jedyny ma restaurację hotelową dostępną tylko dla klientów obiektu.

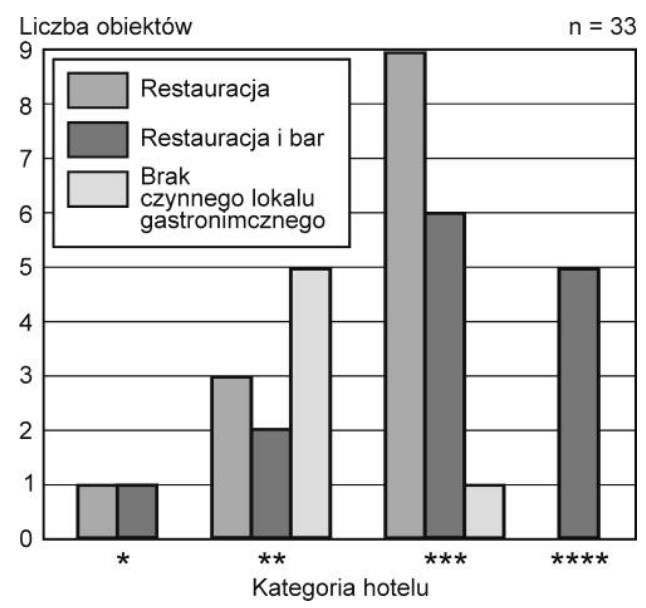

Rys. 1. Rodzaje zakładów gastronomicznych w łódzkich hotelach według kategorii hotelu Źródło: opracowanie własne na podstawie przeprowadzonych badań

Tab. 1. Wymagania dotyczące zakresu usług gastronomicznych i wyposażenia w łódzkich hotelach

\begin{tabular}{|c|c|c|c|c|c|}
\hline \multirow{2}{*}{ Wymagania } & \multicolumn{5}{|c|}{ Kategoria hotelu } \\
\hline & $* * * * *$ & $* * * *$ & $* * *$ & ** & * \\
\hline Sprzedaż gorących napojów przez całą dobę & $x$ & $x$ & $\mathrm{X}^{\mathrm{a}}$ & $\mathrm{x}^{\mathrm{a}}$ & $x^{a}$ \\
\hline Podawanie śniadań & $x$ & $\mathrm{x}$ & $\mathrm{x}$ & $\mathrm{x}$ & $\mathrm{x}$ \\
\hline Aperitif-bar lub bar kawowy & $x$ & $x$ & $x$ & $x$ & - \\
\hline $\begin{array}{l}\text { Restauracja (w hotelu 3-gwiazdkowym dopuszcza się brak restauracji, jeżeli w odległości } \\
\text { maks. } 200 \text { m od obiektu znajduje się restauracja) }\end{array}$ & $\mathrm{x}$ & $\mathrm{x}$ & $\mathrm{x}$ & - & - \\
\hline Podawanie posiłków do j.m. - room service przez co najmniej 18 godz. na dobę & $x$ & $x$ & $\mathrm{x}$ & - & - \\
\hline
\end{tabular}

${ }^{a}$ Dopuszcza się sprzedaż z automatów i w recepcji.

Objaśnienia: $\mathrm{x}$ - wymaganie obowiązuje, $(-)$ - wymaganie nie obowiązuje, j.m. - jednostka mieszkalna.

Źródło: opracowanie własne na podstawie Rozporzadzenia Ministra Gospodarki i Pracy z dnia 19 sierpnia 2004 r. w sprawie obiektów hotelarskich i innych obiektów, w których są świadczone ustugi hotelarskie (Rozporządzenie, 2004). 
Funkcjonowanie restauracji w hotelu zależne jest od przyjętej strategii obiektu, kategorii czy statusu własności. Lokale gastronomiczne mogą być prowadzone w hotelach np. przez odrębne firmy współpracujące $\mathrm{z}$ nimi na określonych warunkach. W Łodzi, przy hotelu Vigo, na tej zasadzie działa znana restauracja Lawasz, w której serwowane są dania kuchni kaukasko-polskiej. Lokal ten jest prowadzony jako osobna działalność gospodarcza. W ramach współpracy z hotelem zajmuje się przygotowywaniem śniadań, room service oraz cateringiem podczas odbywających się w obiekcie konferencji.

\section{MARKA PRODUKTU GASTRONOMICZNEGO W ŁÓDZKICH HOTELACH}

Autorka zbadała markę łódzkich lokali gastronomicznych w hotelach pod kątem trzech czynników: posiadania nazwy własnej, przynależności obiektu do sieci oraz tego, czy hotel jest umiejscowiony w zabytkowym budynku.

Marka (brand) jest to nazwa, symbol, rysunek lub kombinacja tych elementów kreowana w celu identyfikacji dóbr i łatwego odróżnienia ich od konkurencji (Kotler, 1994). Spójna, dobrze wykreowana marka decyduje o charakterze obiektu, jego atmosferze, wpływając na to, jak klienci postrzegają dany obiekt (Wrona, Armatys).

Przynależność hoteli do systemów hotelowych powoduje jednoznaczne skojarzenie marki z istniejącym lokalem gastronomicznym. Kwestią sporną pozostaje, czy powiązanie lokalu gastronomicznego $\mathrm{z}$ hotelem niezrzeszonym lub łańcuchem hotelowym przynosi korzyści czy jest barierą dla potencjalnych gości restauracji. Przynależność do sieci może zapewnić gwarancję wysokiej jakości obsługi, zwiększać popularność lokalu ze względu np. na pozytywną opinię na temat całej sieci hoteli, ale zarazem odstraszać klientów wysokimi cenami (np. jeśli sieć hoteli ma taką opinię) i kojarzyć się $\mathrm{z}$ posiadaniem jednego typu kuchni (np. międzynarodowej, a nie lokalnej). Z kolei przynależność restauracji do hotelu niezrzeszonego może zniechęcać konsumentów ze względu na brak wiedzy o danej marce i skojarzenie $\mathrm{z}$ dostępnością wyłącznie dla gości hotelowych. W Łodzi na 33 hotele 18 obiektów (55\%) jest zrzeszonych - należą one do lokalnych sieci (np. hotele Ambasador), polskich systemów hotelowych (np. Qubus Hotel) oraz międzynarodowych systemów hotelowych (np. AccorHotels).

W ostatnich latach powszechną praktyką stało się sprawdzanie w mediach społecznościowych opinii i poszukiwanie informacji o obiektach gastronomicznych czy hotelach. W tym przypadku istotne jest, czy re- stauracja należy do sieci hotelowej, czy posiada osobną nazwę, gdyż buduje to zupełnie inną społeczność w Internecie - w zależności od sytuacji hotel i restauracja mogą "pracować” na zaufanie klientów osobno lub wspólnie (Kachniewska, 2013). Kwestią dyskusyjną pozostaje odpowiedź na pytanie, czy posiadanie przez lokal osobnej nazwy (innej niż hotel) przynosi więcej korzyści, czy też dla klientów nie ma to znaczenia. Brak nazwy może stanowić barierę dla potencjalnych konsumentów, ponieważ w mediach społecznościowych znajdziemy informacje o zakładzie gastronomicznym tylko pod szyldem hotelu. Wspólna działalność gastronomii i hotelu może skutkować brakiem opinii o restauracji lub trudnościami w dotarciu do nich (Grzegorczyk, 2005).

W Łodzi na 27 opisywanych w niniejszym opracowaniu zakładów gastronomicznych 11 nosi nazwę własną (rys. 2). Nie widać przy tym wyraźnej zależności pomiędzy posiadaniem przez restaurację nazwy a przynależnością do sieci - 5 z 13 obiektów ma nazwę własną w hotelach niezrzeszonych (np. w hotelu Mazowiecki jest restauracja 100łówka). Podobnie w hotelach zrzeszonych - 6 z 14 obiektów ma nazwę własną (np. Restauracja Łódzka w hotelu Holiday Inn). W hotelu Qubus Łódź (należącym do sieci Qubus Hotel) znajdowała się restauracja Ogien, jednak ze względu na ujednolicenie marki sieci w 2018 r. zrezygnowano z osobnej nazwy dla restauracji i hotelu.

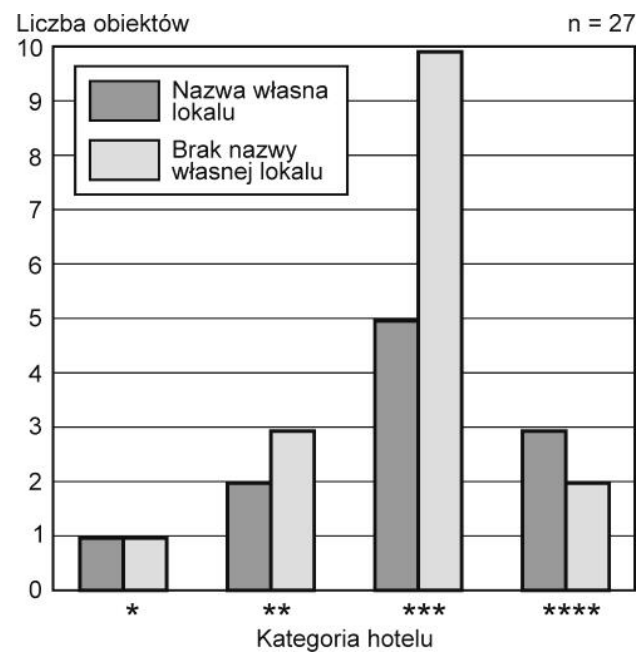

Rys. 2. Łódzkie restauracje hotelowe w podziale na nazwę własną i wspólną z hotelem Źródło: opracowanie własne

Podstawą kreowania marki lokalu gastronomicznego może być jego historia lub lokalizacja w zabytkowym obiekcie. W Łodzi znajduje się siedem hoteli w budynkach z XIX i XX w. (tab. 2), wpisanych do rejestru zabytków. 
Tab. 2. Łódzkie hotele w obiektach zabytkowych

\begin{tabular}{|c|c|c|c|c|c|c|}
\hline Lp. & Nazwa hotelu & Restauracja & Czas powstania & $\begin{array}{l}\text { Wcześniejsze funkcja } \\
\text { budynku }\end{array}$ & $\begin{array}{l}\text { Data wpisu } \\
\text { do rejestru } \\
\text { zabytków }\end{array}$ & $\begin{array}{l}\text { Adres } \\
\text { (ulica) }\end{array}$ \\
\hline 1. & Polonia & $\begin{array}{l}\text { brak czynnego lokalu } \\
\text { gastronomicznego }\end{array}$ & 1910-1912, 1953 & hotel Palast & 31.03.1994 & Kilińskiego 52 \\
\hline 2. & Reymont & $\begin{array}{l}\text { brak czynnego lokalu } \\
\text { gastronomicznego }\end{array}$ & 1927 & domy wojskowe & 20.01.1971 & Legionów 81/83 \\
\hline 3. & Focus & restauracja hotelowa & 1897 & $\begin{array}{c}\text { Fabryka Towarów } \\
\text { Bawełnianych Juliusza } \\
\text { Kindermana } \\
\end{array}$ & 27.12.1982 & Łąkowa 23/25 \\
\hline 4. & Grand Hotel & restauracja Grand & $\begin{array}{c}1872 \text { r., } \\
\text { przebudowa } \\
1887-1888\end{array}$ & nie dotyczy & brak danych & Piotrkowska 72 \\
\hline 5. & Savoy & $\begin{array}{l}\text { brak czynnego lokalu } \\
\text { gastronomicznego }\end{array}$ & lata 1910-1911 & nie dotyczy & 28.12.2010 & Traugutta 6 \\
\hline 6. & $\begin{array}{l}\text { Vienna House } \\
\text { Andel's Łodz }\end{array}$ & restauracja Delight & $\begin{array}{l}\text { lata } 70 . \\
\text { i } 90 . \text { XIX w. }\end{array}$ & $\begin{array}{l}\text { zespół budownictwa } \\
\text { przemysłowego } \\
\text { I.K. Poznańskiego }\end{array}$ & 14.09 .1993 & Ogrodowa 17 \\
\hline 7. & Tobaco & $\begin{array}{c}\text { Restauracja } \\
\text { u Kretschmera }\end{array}$ & lata 30. XX w. & $\begin{array}{c}\text { budynek Fabryki } \\
\text { Monopolu } \\
\text { Tytoniowego }\end{array}$ & 20.01 .1971 & Kopernika 60/64 \\
\hline
\end{tabular}

Źródło: opracowanie własne na podstawie Rejestru i ewidencji zabytków (Wojewódzki Urząd Ochrony Zabytków w Łodzi, 2018).

$\mathrm{W}$ trzech $\mathrm{z}$ siedmiu hoteli mieszczących się $\mathrm{w}$ zabytkowych budynkach nie ma obecnie czynnej restauracji. Ciekawym przykładem jest hotel Grand, będący jedynym przedsiębiorstwem znajdującym się w zabytkowym obiekcie, które nie zmieniło swojej funkcji oraz nazwy od początku istnienia. Hotel ten działa nieprzerwanie od ponad 130 lat. Dodatkową atrakcją dla konsumentów korzystających $\mathrm{z}$ restauracji może być możliwość zobaczenia wnętrz legendarnego hotelu, na co dzień nieudostępnianego do zwiedzania. Goście, spożywając posiłek w zabytkowych salach, mają okazję obejrzeć detale architektoniczne, zwrócić uwagę na wystrój pomieszczeń, poznać historię obiektu i dzieje miasta, a dzięki tym wszystkim elementom - poczuć klimat dawnej Łodzi (Grand Hotel Łódź).

\section{LOKALNA KUCHNIA JAKO ELEMENT PRODUKTU GASTRONOMICZNEGO}

Do II wojny światowej Łódź była miastem czterech kultur: żydowskiej, niemieckiej, rosyjskiej i polskiej. Ich wzajemne przenikanie się odcisnęło piętno m.in. na lokalnej gastronomii, a relikty kuchni etnicznych widoczne są do dziś (Stasiak, 2015; Wojciechowska, 2014).

Od 2004 r. polskie Ministerstwo Rolnictwa i Rozwoju Wsi $\mathrm{w}$ ramach ochrony tradycyjnie wytwarzanych produktów prowadzi program ich promocji, wsparcia i zabezpieczania. W styczniu 2019 r. na liście znajdowały się 1864 produkty tradycyjne i regionalne, z czego
141 pochodziło z województwa łódzkiego (Ministerstwo Rolnictwa i Rozwoju Wsi). Niestety łódzkie produkty z listy nie są na tyle rozpoznawalne, by powszechnie kojarzyły się z tradycyjną łódzką kuchnią.

Menu wielu restauracji w Łodzi, również znajdujących się w hotelach, zawiera odwołania do jej historii i dziedzictwa kulturowego. Na przykład Restauracja u Kretschmera w hotelu Taboco nawiązuje do historii miasta nie tylko nazwą, ale także swoją kuchnią. W menu znajdują się potrawy kuchni czterech kultur związanych z Łodzią, przyrządzane w nowoczesnej odsłonie, ale według tradycyjnych przepisów. Restauracja Łódzka, mieszcząca się w hotelu Holiday Inn Łódź, ma przygotowany dla klientów dodatek $\mathrm{w}$ menu na podstawie książki Fifka i Żulik, czyli domowa kuchnia tódzka (Dziennik Łódzki). Anna Wojciechowska, autorka publikacji, zebrała przepisy odwołujące się do tradycyjnej łódzkiej kuchni, którą nazywa kuchnią dawnej robotniczej Łodzi. Przepisy zawarte w książce wykorzystywane były od pokoleń $\mathrm{w}$ domu autorki, ale sa także wynikiem poszukiwań w literaturze (Wojciechowska, 2014).

Gestorzy, korzystając z dziedzictwa kulinarnego miasta, mogą stworzyć unikatowy dla danego obszaru produkt gastronomiczny hotelu. Dzięki coraz większej świadomości i wiedzy na temat żywienia klienci zwracają zdecydowanie większą uwagę na skład i pochodzenie poszczególnych produktów. Wykorzystanie produktów lokalnych, z danego regionu, wpływa na postrzeganie marki hotelu. Buduje wizerunek obiektu wspierającego małych przedsiębiorców oraz dbającego o jakość podawanych potraw. 


\section{DOSTĘPNOŚĆ PRODUKTU GASTRONOMICZNEGO W ŁÓDZKICH HOTELACH}

Autorka w badaniu wybrała dwie cechy obiektów, które jej zdaniem odnoszą się do dostępności produktów gastronomicznych w hotelach - godziny otwarcia oraz odległość restauracji hotelowych od najpopularniejszych 10 łódzkich zabytków wymienionych w portalu TripAdvisor (TripAdvisor).

W Polsce zwyczajowo restauracje (poza obiektami noclegowymi) otwarte są bez przerw w ciągu dnia, odmienienie niż w krajach śródziemnomorskich, gdzie lokale tego typu są zamykane na czas sjesty, w zależności od państwa między 13.00 a 17.00. Przyjęte jest, że obiad/lunch ogólnie w Europie najczęściej spożywany jest od 14.00 do 16.00, w Europie Zachodniej wcześniej - między 12.00 a 14.00, zaś w Europie Środkowej i Wschodniej w godzinach późniejszych. W wielu krajach jednak to kolacja, jadana po godzinie 18.00, jest najbardziej urozmaiconym i wykwintnym posiłkiem (Sala, 2011).

W Łodzi wyróżniamy restauracje hotelowe czynne: - przez cały dzień,

- z przerwą w czasie lunchu/obiadu,

- na dwie zmiany - w czasie śniadań oraz w godzinach popołudniowych.

Godziny otwarcia zależą od działalności dodatkowej, jaką prowadzi obiekt. W hotelach, w których organizowane są konferencje, restauracje $\mathrm{w}$ porze lunchu są często zarezerwowane wyłącznie dla grup konferencyjnych. Duże hotele, ze względu na organizację śniadań, po zakończeniu pory śniadaniowej zamykają zakład gastronomiczny. W tym czasie wprowadzane są zmiany, np. obsługi, kucharzy czy wystroju wnętrza, a restauracja otwierana jest dopiero po południu. W Łodzi jest 16 obiektów mających lokal czynny bez żadnych przerw (rys. 3). Brak ciągłości w godzinach otwarcia może utrudniać korzystanie z lokalu potencjalnym konsumentom, którzy nie mogą swobodnie przychodzić do restauracji, zgodnie ze swoimi potrzebami lub przyzwyczajeniami uwarunkowanymi kulturowo.

Autorka za kolejny ważny element uznała lokalizację produktu gastronomicznego względem 10 najpopularniejszych łódzkich obiektów według portalu TripAdvisor. Na podstawie opinii i komentarzy użytkowników na stronie generowany jest ranking najpopularniejszych miejsc. W Łodzi wyróżniono osiem obiektów (Centrum Handlowe Manufaktura; Muzeum Tradycji Niepodległościowych w Łodzi, Oddział Stacja Radegast; cmentarz żydowski; Księży Młyn; pałac Herbsta; Pasaż Róży; Planetarium EC1; Ogród Botaniczny im. Jakuba Mowszowicza), ulicę Piotrkowską (całą, a nie wybrane adresy) oraz obszar Lasu Łagiewnickiego.
Spośród 27 hoteli 11 znajduje się w pobliżu przynajmniej jednego z wybranych obiektów. Hotel Grand i hotel Holiday Inn są zlokalizowane przy ulicy Piotrkowskiej (rys. 4).

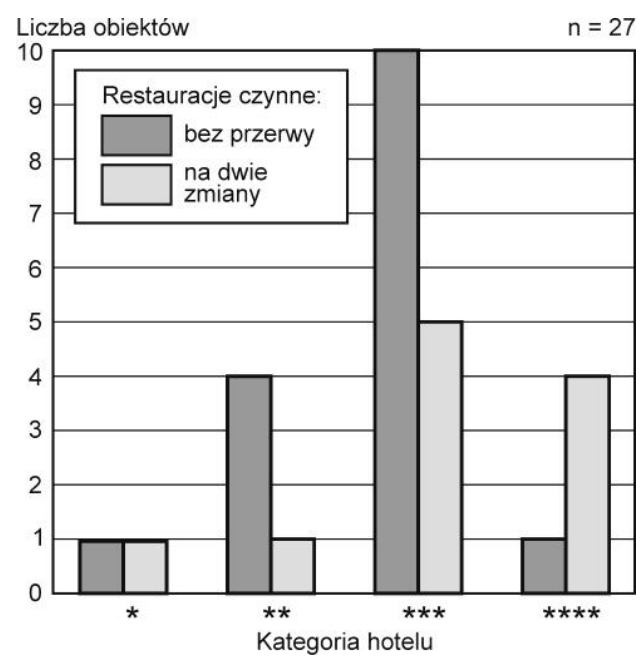

Rys. 3. Godziny otwarcia restauracji hotelowych $\mathrm{w}$ Łodzi według podziału na kategorie hoteli Źródło: opracowanie własne na podstawie przeprowadzonych badan

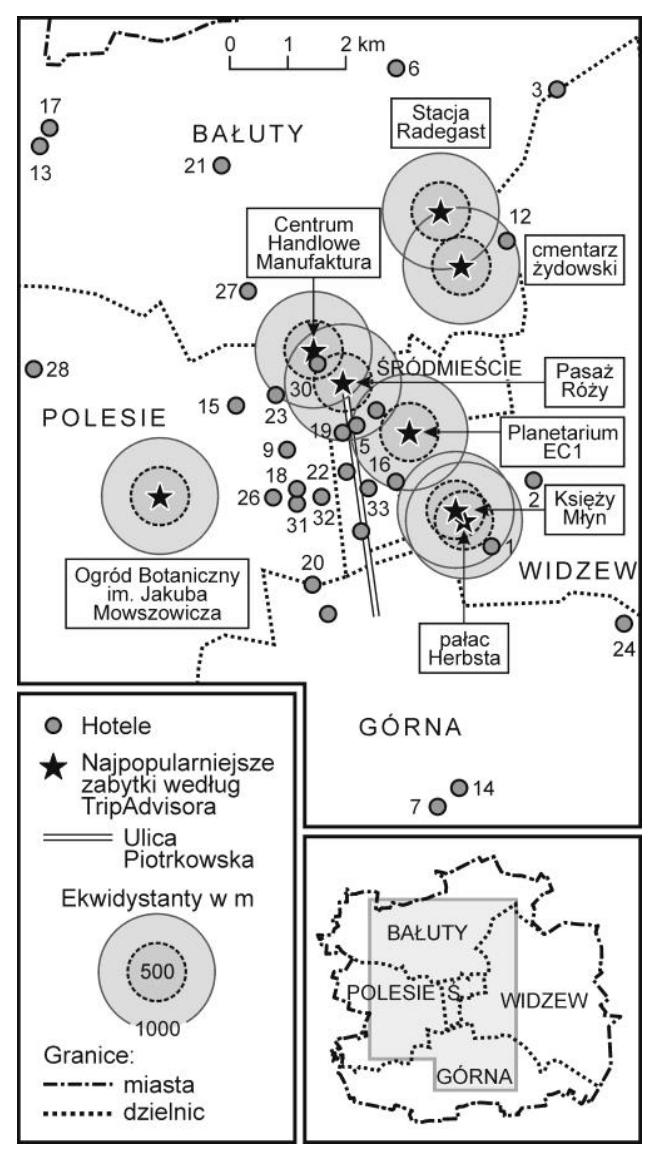

Rys. 4. Rozmieszczenie hoteli względem wybranych najpopularniejszych

łódzkich obiektów według portalu TripAdvisor Źródło: opracowanie własne 
Położenie hoteli względem wyróżnionych najpopularniejszych obiektów $\mathrm{w}$ mieście oddziałuje na gastronomię hotelową na dwa sposoby - jako czynnik, który powoduje albo wybór hotelu (turysta chce mieszkać blisko wybranego zabytku, obiektu) albo znajdującej się w nim restauracji (po odwiedzeniu danego zabytku/miejsca turysta może pójść do znajdującego się $\mathrm{w}$ hotelu lokalu gastronomicznego, nie korzystając $\mathrm{z}$ noclegu).

\section{PODSUMOWANIE}

W tab. 3 przedstawiono zestawienie łódzkich hoteli z czynnymi restauracjami. W zestawieniu autorka oceniła produkt gastronomiczny hoteli pod kątem wcześniej omówionych wybranych cech. Do oceny zastosowano skalę, w której 0 oznacza niespełnienie danego wymagania, a 1 - spełnienie. Za położenie blisko zabytków, niezależnie od liczby obiektów, autorka przyznawała 0 punktów lub 1 punkt. Najwyższą notę dostało sześć obiektów - jeden obiekt otrzymał cztery punkty (hotel Tobaco - Restauracja u Kretschmera), pięć obiektów uzyskało trzy punkty. Zero punktów otrzymały cztery obiekty.

Niewątpliwie wyróżnione w badaniu zakłady gastronomiczne zasługują na szczególną uwagę, zwłaszcza lokal w hotelu Tobaco (Restauracja u Kretschmera) oraz w Vienna House Andel's Lodz (Delight). Obie restauracje hotelowe doceniono bowiem już kilkakrotnie $\mathrm{w}$ różnorodnych kulinarnych konkursach (Vienna House, hotel Tobaco). Zostały one wysoko ocenione m.in. w Żóttym przewodniku Gault \& Millau. Jest to jedna z dwóch prestiżowych serii wydawniczych (obok przewodników Michelina) recenzujących rynek ga- stronomiczny (Horecanet.pl). Na 640 restauracji, którym przyznano wyróżnienia w Polsce na rok 2019, 18 restauracji było $\mathrm{z}$ Łodzi, $\mathrm{w}$ tym dwie mieszczące się $\mathrm{w}$ hotelach. Restauracja u Kretschmera na rok 2019 czwarty raz z rzędu otrzymała czapę kucharską (na pięć polskich edycji konkursu) (Koper, 2018).

Stasiak (2015), analizując różne aspekty łódzkiej gastronomii i rozpatrując możliwości wypromowania kulinarnej atrakcji turystycznej miasta, nie podjął tematu gastronomii $\mathrm{w}$ hotelach. Zdaniem autorki odpowiednia promocja gastronomii hotelowej może jednak przełamać negatywny i fałszywy stereotyp tych lokali, które wielu ludzi uważa za dostępne tylko dla gości hotelowych, a także spowodować dotarcie do nowej grupy odbiorców zainteresowanych turystyką kulinarną. Odrębna, niezależna od hotelu nazwa zakładu gastronomicznego może ułatwić prowadzenie kampanii reklamowych, szczególnie $\mathrm{w}$ mediach społecznościowych. Z kolei ustalenie stałych godzin otwarcia pomoże zwiększyć dostępność restauracji oraz zachęcić do korzystania z nich osoby niebędące gośćmi hotelowymi. Bliskość najważniejszych zabytków Łodzi zaś powinna zachęcać managerów lokali do współpracy z miejskimi przewodnikami.

Korzystając z gastronomii hotelowej - zwłaszcza w zabytkowych obiektach, w których serwowana jest kuchnia nawiązująca do historii miasta - mieszkańcy i turyści mają okazję poznać Łódź od zupełnie innej strony. Mogą odkrywać i podziwiać oryginalne wnętrza łódzkich pałaców i fabryk, próbując nowych potraw, a pobyt $\mathrm{w}$ restauracji może stać się pretekstem do opowiadania historii o dawnych mieszkańcach miasta. Dla hotelarzy z kolei może to być możliwość dodatkowej promocji i wzrostu dochodów, a także źródło inspiracji do kreowania marki swojego lokalu, która komponowałaby się $\mathrm{z}$ historią miasta.

Tab. 3. Produkt gastronomiczny w łódzkich hotelach posiadających restaurację

\begin{tabular}{|c|c|c|c|c|c|c|c|c|c|c|}
\hline \multirow{3}{*}{$\begin{array}{l}\text { Nazwa } \\
\text { hotelu }^{\text {a }}\end{array}$} & \multirow{3}{*}{$\begin{array}{c}\text { Kategoria } \\
\text { hotelu }\end{array}$} & \multirow{3}{*}{$\begin{array}{l}\text { Nazwa } \\
\text { restauracji } \\
\text { hotelowej }\end{array}$} & \multicolumn{8}{|c|}{ Cechy produktu gastronomicznego hotelu } \\
\hline & & & \multirow{2}{*}{$\begin{array}{l}\text { Nazwa } \\
\text { własna } \\
\text { lokalu }\end{array}$} & \multirow{2}{*}{$\begin{array}{c}\text { Kuchnia } \\
\text { lokalna, } \\
\text { związana } \\
\text { z tradycją } \\
\text { miasta }\end{array}$} & \multirow{2}{*}{$\begin{array}{c}\text { Ciągłe } \\
\text { godziny } \\
\text { otwarcia } \\
\text { obiektu }\end{array}$} & \multicolumn{3}{|c|}{ Odległość od wybranych zabytków } & \multirow{2}{*}{$\begin{array}{c}\text { Lokalizacja } \\
\text { w zabyt- } \\
\text { kowym } \\
\text { obiekcie }\end{array}$} & \multirow{2}{*}{ Suma } \\
\hline & & & & & & $\begin{array}{l}\text { Dostęp- } \\
\text { ność }\end{array}$ & $0,5 \mathrm{~km}$ & $1 \mathrm{~km}$ & & \\
\hline Nu Hotel (2) & * & RH & 0 & 0 & 0 & 0 & 0 & 0 & 0 & 0 \\
\hline Alicja (4) & $* *$ & RH & 0 & 0 & $\begin{array}{c}\text { nie } \\
\text { dotyczy }\end{array}$ & 0 & 0 & 0 & 0 & 0 \\
\hline $\begin{array}{l}\text { Ambasador } \\
\text { Chojny (14) }\end{array}$ & $* * *$ & RH & 0 & 0 & 0 & 0 & 0 & 0 & 0 & 0 \\
\hline Qubus (22) & $* * *$ & RH & 0 & 0 & 0 & 0 & 0 & 0 & 0 & 0 \\
\hline $\begin{array}{l}\text { Mazowiecki } \\
(9)\end{array}$ & $* *$ & 100łówka & 1 & 0 & 0 & 0 & 0 & 0 & 0 & 1 \\
\hline Mhotel (13) & $* * *$ & $\mathrm{RH}$ & 0 & 0 & 1 & 0 & 0 & 0 & 0 & 1 \\
\hline
\end{tabular}


Tab. 3 (cd.)

\begin{tabular}{|c|c|c|c|c|c|c|c|c|c|c|}
\hline \multirow{3}{*}{$\begin{array}{l}\text { Nazwa } \\
\text { hotelu }^{a}\end{array}$} & \multirow{3}{*}{$\begin{array}{c}\text { Kategoria } \\
\text { hotelu }\end{array}$} & \multirow{3}{*}{$\begin{array}{l}\text { Nazwa } \\
\text { restauracji } \\
\text { hotelowej }\end{array}$} & \multicolumn{8}{|c|}{ Cechy produktu gastronomicznego hotelu } \\
\hline & & & \multirow{2}{*}{$\begin{array}{l}\text { Nazwa } \\
\text { własna } \\
\text { lokalu }\end{array}$} & \multirow{2}{*}{$\begin{array}{c}\text { Kuchnia } \\
\text { lokalna, } \\
\text { związana } \\
\text { z tradycją } \\
\text { miasta }\end{array}$} & \multirow{2}{*}{$\begin{array}{c}\text { Ciągłe } \\
\text { godziny } \\
\text { otwarcia } \\
\text { obiektu }\end{array}$} & \multicolumn{3}{|c|}{ Odległość od wybranych zabytków } & \multirow{2}{*}{$\begin{array}{c}\text { Lokalizacja } \\
\text { w zabyt- } \\
\text { kowym } \\
\text { obiekcie }\end{array}$} & \multirow{2}{*}{ Suma } \\
\hline & & & & & & $\begin{array}{c}\text { Dostęp- } \\
\text { ność }\end{array}$ & $0,5 \mathrm{~km}$ & $1 \mathrm{~km}$ & & \\
\hline $\begin{array}{l}\text { Iness Hotel } \\
(20)\end{array}$ & $* * *$ & RH & 0 & 0 & 1 & 0 & 0 & 0 & 0 & 1 \\
\hline Rubin (24) & $* * *$ & $\mathrm{RH}$ & 0 & 0 & 1 & 0 & 0 & 0 & 0 & 1 \\
\hline Yuca (28) & $* * *$ & RH & 0 & 0 & 1 & 0 & 0 & 0 & 1 & 1 \\
\hline $\begin{array}{l}\text { Doubletree } \\
\text { by Hilton } \\
\text { Eódź (31) }\end{array}$ & $* * * *$ & Four Colors & 1 & 0 & 0 & 0 & 0 & 0 & 0 & 1 \\
\hline Flora (17) & $* * *$ & $\mathrm{RH}$ & 0 & 0 & 1 & 0 & 0 & 0 & 0 & 1 \\
\hline $\begin{array}{l}\text { Ambasador } \\
\text { Centrum (29) }\end{array}$ & $* * * *$ & $\mathrm{RH}$ & 0 & 0 & 1 & 1 & ul. Piotrkowska & Planetarium EC1 & 0 & 2 \\
\hline Agat (3) & $* *$ & RH & 0 & 0 & 1 & 1 & $\begin{array}{c}\text { tereny Lasu } \\
\text { Łagiewnickiego }\end{array}$ & 0 & 0 & 2 \\
\hline Ibis (8) & $* *$ & $\mathrm{RH}$ & 0 & 0 & 1 & 1 & ul. Piotrkowska & 0 & 0 & 2 \\
\hline $\begin{array}{l}\text { Borowiecki } \\
\text { (15) }\end{array}$ & $* * *$ & $\begin{array}{l}\text { Tkalnia } \\
\text { Smaków }\end{array}$ & 1 & 0 & 1 & 0 & 0 & 0 & 0 & 2 \\
\hline $\begin{array}{l}\text { Focus } \\
\text { Hotel (18) }\end{array}$ & $* * *$ & RH & 0 & 0 & 1 & 0 & 0 & 0 & 1 & 2 \\
\hline $\begin{array}{l}\text { Nobo Hotel } \\
(21)\end{array}$ & $* * *$ & Kolory Wina & 1 & 0 & 1 & 0 & 0 & 0 & 0 & 2 \\
\hline $\begin{array}{l}\text { Światowit } \\
(25)\end{array}$ & $* * *$ & RH & 0 & 0 & 1 & 1 & ul. Piotrkowska & 0 & 0 & 2 \\
\hline Vigo (27) & $* * *$ & Lawasz & 1 & 0 & 1 & 0 & 0 & 0 & 0 & 2 \\
\hline $\begin{array}{l}\text { Novotel Łódź } \\
\text { Centrum (33) }\end{array}$ & $* * * *$ & RH & 0 & 0 & 1 & 1 & 0 & ul. Piotrkowska & 0 & 2 \\
\hline $\begin{array}{l}\text { Campanile } \\
\text { (16) }\end{array}$ & $* * *$ & $\mathrm{RH}$ & 0 & 0 & 1 & 1 & 0 & $\begin{array}{l}\text { ul. Piotrkowska, } \\
\text { Księży Młyn, } \\
\text { Planetarium EC1 }\end{array}$ & 0 & 2 \\
\hline Skarpa (12) & $* *$ & Skarabeusz & 1 & 0 & 1 & 1 & 0 & $\begin{array}{l}\text { cmentarz ży- } \\
\text { dowski }\end{array}$ & 0 & 3 \\
\hline $\begin{array}{l}\text { Holiday Inn } \\
\text { Łódź (32) }\end{array}$ & $* * * *$ & $\begin{array}{c}\text { Restauracja } \\
\text { Lódzka }\end{array}$ & 1 & 1 & 0 & 1 & ul. Piotrkowska & 0 & 0 & 3 \\
\hline Boss (1) & $*$ & $\begin{array}{c}\text { Polskie } \\
\text { Smaki }\end{array}$ & 1 & 0 & 1 & 1 & 0 & $\begin{array}{l}\text { Księży Młyn, } \\
\text { pałac Herbsta }\end{array}$ & 0 & 3 \\
\hline $\begin{array}{l}\text { Grand } \\
\text { Hotel (19) }\end{array}$ & $* * *$ & Grand & 1 & 0 & 0 & 1 & ul. Piotrkowska & $\begin{array}{l}\text { Pasaż Róży, } \\
\text { Planetarium } \\
\text { EC } 1\end{array}$ & 1 & 3 \\
\hline $\begin{array}{l}\text { Andel's } \\
\text { Hotel Łódź } \\
\text { (30) }\end{array}$ & $* * * *$ & Delight & 1 & 0 & 0 & 1 & $\begin{array}{l}\text { Manufaktura, } \\
\text { Pasaż Róży }\end{array}$ & ul. Piotrkowska & 1 & 3 \\
\hline Tobaco (26) & $* * *$ & $\begin{array}{c}\text { Restauracja } \\
\text { u Kretsch- } \\
\text { mera }\end{array}$ & 1 & 1 & 1 & 0 & 0 & 0 & 1 & 4 \\
\hline
\end{tabular}

a Obok nazwy każdego hotelu w nawiasach podano oznaczenie hotelu na mapie znajdującej się na rys. 4.

Objaśnienie znaków i skrótów: 1 - tak, 0 - nie, RH - restauracja hotelowa.

Źródło: opracowanie własne. 


\section{BIBLIOGRAFIA}

Björk, P., Kauppinen-Räisänen, H. (2017). A destination's gastronomy as a means for holiday well-being. British Food Journal, 119 (7), 1578-1591.

Centralna Ewidencja i Wykazy w Turystyce, Ministerstwo Turystyki. Pobrane z: www.turystyka.gov.pl (20.01.2019).

Czarnecka-Skubina, E., Głuchowski, A., Rasińska, E. (2017). Rynek usług gastronomicznych $\mathrm{w}$ Polsce na przykładzie Warszawy. Handel Wewnętrzny, 4 (369/2), 118-133.

Dziennik Łódzki. Pobrane z: www.dzienniklodzki.pl/tradycyjnalodzka-kuchnia-w-hotelu-holiday-inn-zdjeciafilm/ar/3803633 (20.01.2019)

Gordin, V., Trabskaya, J., Zelenskaya, E. (2016). The role of hotel restaurants in gastronomic place branding. International Journal of Culture, Tourism and Hospitality Research, 10, 81-90.

Grand Hotel Łódź. Pobrane z: www.grand.hotel.com.pl (20.01.2019).

Grzegorczyk, A. (2005). Marka jest nazwą. Definiens marki. W: A. Grzegorczyk (red.), Instrumenty ksztaltowania wizerunku marki (s. 1-7). Warszawa: Wyższa Szkoła Promocji.

Horecanet.pl. Pobrane z: www.horecanet.pl/piata-gala-zoltegoprzewodnika-gault-millau-za-nami/ (20.01.2019).

Hotel Tobaco. Pobrane z: www.hoteltobaco.pl (20.01.2019).

InterSIT. Pobrane z: www.mapa.lodz.pl (20.01.2019).

Jędrysiak, T., Orłowski, D., Woźniczko, M. (2015). Turystyka kulinarna. Warszawa: PWE.

Kapera, I. (2015). Hotel gastronomy as viewed by customers. Food Journal, 117, 2993-3002.

Koper, H. (2018). Coraz więcej łódzkich restauracji wyróżnionych $w$ "Żóttym przewodniku Gault \& Millau”. Pobrane z: www.lodz. travel/aktualnosci-lodzkiej-organizacji-turystycznej/artykullot/coraz-wiecej-lodzkich-restauracji-wyroznionych-w-zoltymprzewodniku-gault-millau-id24650/2018/11/29/ (20.01.2019).

Kotler, P. (1994). Marketing. Analiza, planowanie, wdrażanie i kontrola. Warszawa: Gebethner \& Ska.

Kozłowska, A. (2015). Wybrane wydarzenia gastronomiczne w Łodzi jako efekt trendów europejskich. W: B. Krakowiak, A. Stasiak (red.), Kultura i turystyka - wokót wspólnego stotu (s. 333-356). Łódź: Regionalna Organizacja Turystyczna Województwa Łódzkiego, Instytut Geografii Miast i Turyzmu Uniwersytetu Łódzkiego.

Krakowiak, B., Stasiak, A. (red.) (2015). Kultura i turystyka - wokót wspólnego stotu. Łódź: Regionalna Organizacja Turystyczna
Województwa Łódzkiego, Instytut Geografii Miast i Turyzmu Uniwersytetu Łódzkiego.

Kuchniewska, M. (2013). Media społecznościowe jako narzędzie nowoczesnego marketingu usług hotelarskich. W: P. Dominik (red.), Innowacyjne rozwiazania we wspótczesnym hotelarstwie (s. 106-121). Warszawa: Almamer.

Kwiatkowska, E., Levytska, G. (2009). Rynek usług gastronomicznych w Polsce na początku XXI w. Zeszyty Naukowe SGGW Ekonomika i Organizacja Gospodarki Żywnościowej Warszawa, 74, 91-102.

Milewska, M., Włodarczyk, B. (2015). Hotelarstwo. Podstawowe wiadomości. Warszawa: PWE.

Milewska, M., Prączko, A., Stasiak, A. (2017). Podstawy gastronomii. Od żywności do turystyki kulinarnej. Warszawa: PWE.

Ministerstwo Rolnictwa i Rozwoju Wsi. Pobrane z: www.gov.pl/ web/rolnictwo/produkty-regionalne-i-tradycyjne1 (20.01.2019).

Rozporzadzenie Ministra Gospodarki i Pracy z 19.08.2004 r. w sprawie obiektów hotelarskich $i$ innych obiektów, w których sa świadczone ustugi hotelarskie. DzU. 2004, nr 188, poz. 1945.

Sala, J. (2011). Marketing w gastronomii. Warszawa: PWE.

Stasiak, A. (2007). Gastronomia jako produkt turystyczny. Turystyka i Hotelarstwo, 11, 103-129.

Stasiak, A. (2015). Gastronomia jako atrakcja turystyczna Łodzi. Turyzm/Tourism, 25 (2), 77-90.

TripAdvisor. Pobrane z: www.pl.tripadvisor.com/Attractionsg274837-Activities-Lodz_Lodz_Province_Central_Poland.html (20.01.2019)

Ustawa z 29.08.1997 r. o ustugach hotelarskich oraz ustugach pilotów wycieczek i przewodników turtycznych. DzU. 1997, nr 133, poz. 884.

Vienna House. Pobrane z: www.viennahouse.com (20.01.2019).

Włodarczyk, B. (2015). Hotele w przestrzeni miejskiej Łodzi. Turyzm/Tourism, 25 (2), 63-75.

Wojciechowska, A. (2014). Fifka i żulik, czyli domowa kuchnia tódzka. Łódź: Centrum Inicjatyw na Rzecz Rozwoju „Regio”.

Wojewódzki Urząd Ochrony Zabytków w Łodzi, 2018. Pobrane z: www.wuoz-lodz.pl/Rejestr_i_ewidencja_zabytkow,19 (20.01.2019).

Wrona, D., Armatys, K. Marka. Pobrane z: https://mfiles.pl/ $\mathrm{pl}$ /index.php/Marka (20.01.2019).

Artykuł wpłynął: 6 stycznia $2019 \mathrm{r}$. Zaakceptowano do druku: 1 marca $2019 \mathrm{r}$ 